\title{
PROTOTYPE ALAT TAKAR OTOMATIS BERBASIS ARDUINO UNO UNTUK PELAKU USAHA PENGERINGAN "EMPON-EMPON" DI KISMANTORO WONOGIRI
}

\author{
Ary Eswara Sunaryo ${ }^{1}$, Rudi Susanto ${ }^{2}$ \\ ${ }^{1,2}$ STMIK Duta Bangsa Surakarta, Indonesia. J1. Bhayangara no 55 Tipes, Surakarta \\ Email:ary.eswara.s@gmail.com
}

\begin{abstract}
ABSTRAK
Penakaran adalah salah satu proses yang dilakukan dalam rangka pengemasan produk. Otomatisasi proses penakaran dapat mempersingkat waktu pengemasan sebuah produk. Tujuan penelitian ini adalah untuk merancang dan membangun Prototype Alat Takar Otomatis berbasis Arduino Uno dengan load sensor dan modul HX711 yang diharapkan dapat memberikan sumbangan pemikiran dalam memperkaya literatur untuk pembagunan alat takar otomatis yang dapat diterapkan pada usaha "empon-empon" maupun usaha sejenisnya untuk proses penakaran secara otomatis suatu produk. Metode pelaksanaan penelitian ini adalah sebagai berikut: 1) Pembuatan desain 2), Pembuatan prototype alat, 3) Pengujian dan analisis data.
\end{abstract}

Kata-kata kunci: alat takar, Arduino uno, load sensor, hx711

\section{PENDAHULUAN}

Empon-empon merupakan tanaman yang memiliki khasiat obat, contohnya adalah: jahe, lengkuas, kencur, kunyit, temu lawak dan lain-lain (Utami, 2013). Dalam rangka pemasaran produk perlu dilakukan pengemasan agar produk terlindungi dan pengemasan akan meningkatkan harga jual suatu produk.

Dalam pengemasan suatu produk, penakaran adalah proses yang wajib dilakukan untuk menjamin keseragaman antara isi kemasan satu dengan lainya. Proses penakaran manual memerlukan tenaga dan waktu. Dalam proses pengemasan skala industri sudah diterapkan mekanisme pengemasan dan penakaran secara otomatis yang akan mempercepat proses pengemasan suatu produk. Akan tetapi harga mesin otomatis tidaklah murah.

Oleh karena itu penulis mencoba merancang sebuah prototype alat takar otomatis yang dapat mempermudah dan mempersingkat waktu penakaran produk khususnya empon-empon. Produk emponempon dalam jumlah besar akan masuk ke alat dan akan di keluarkan sesuai takaran yang sudah di atur sebelumnya.

\section{METODE}

Metode penelitian ini adalah sebagai berikut 1)Pembuatan desain, 2)Pembuatan prototype alat, 3)Pengujian dan analisis data.

1)Pembuatan desain. Pada tahap pembuatan desain dilakukan dalam tiga bagian yaitu pembuatan desain mekanik alat yang dilakukan menggunakan software fusion 360, pembuatan desain rangkaian elektronik menggunakan software Proteus 8 Professional, dan desain Cara kerja alat yang dijelaskan melalui diagram alir.

2)Pembuatan prototype alat. Setelah desain mekanik alat dibuat melalui software fusion 360 selesai, proses selanjutnya adalah pembuatan prototype. Sebagian komponen mekanik alat dibuat menggunakan mesin cetak 3D dan Sebagian lagi menggunakan barang bekas. Setelah semua komponen alat terkumpul 
maka bagian mekanik alat siap di rangkai. Kemudian komponen elektronik ditambahkan sesuai desain rangkaian yang telah dibuat pada software Proteus 8 Professional. Kemudian alat di program menggunakan software Arduino IDE.

3)Pengujian dan analisis data. Proses pengujian dilakukan dengan menjalankan alat sebanyak 10 kali sehingga kemudian didapatkan 10 sampel takaran produk. Sampel produk tersebut kemudian di timbang dengan timbangan kue. Kemudian membandingkan nilai keluaran sensor alat dengan hasil timbangan kue.

\section{HASIL DAN PEMBAHASAN}

Pembuatan desain prototype alat takar otomatis dibagi kedalam dua tahap yaitu pembuatan desain mekanik alat dan desain elektronik alat. Secara umum desain mekanik alat seperti Gambar 1.

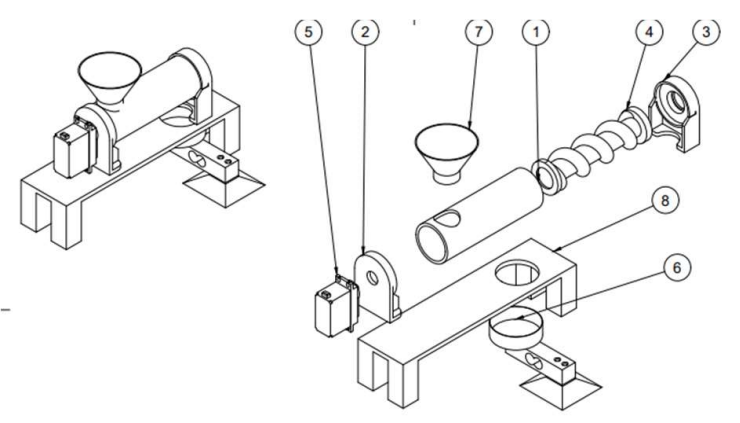

Gambar 1. Desain mekanik alat

\begin{tabular}{|c|c|l|l|l|}
\hline 8 & 1 & Meja & Tempat alat dirangkai & Akrilik \\
\hline 7 & 1 & Corong & Tempat produk masuk & \\
\hline 6 & 1 & Load sensor & Sensor berat & HX711 \\
\hline 5 & 1 & Servo & Memutar Lead Screw & \\
\hline 4 & 1 & Lead Screw & Dorong produk ke load sensor & Cetak 3D \\
\hline 3 & 1 & CapB & & Cetak 3D \\
\hline 2 & 1 & CapA & Cetak 3D \\
\hline 1 & 1 & Barel & Description & Material \\
\hline Item & Qty & Part Number & Parts List \\
\hline \multicolumn{5}{|c|}{} \\
\hline
\end{tabular}

Gambar 2. Keterangan komponen Gambar 1

Desain rangkaian elektronik yang terdiri dari Arduino Uno, Continuous Servo dan Load Sensor + modul HX711 seperti terlihat pada Gambar 3.
Continuous Servo yang dipakai pada penelitian ini adalah Servo biasa yang dimodifikasi menjadi Continuous.

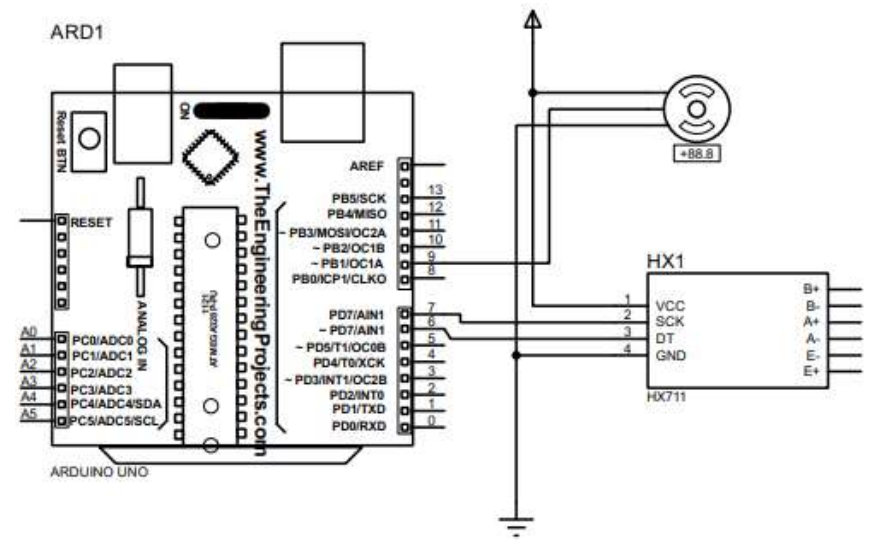

Gambar 3. Desain Rangkaian Elektronik

Cara kerja alat takar otomatis ini cukup sederhana yaitu, pada awalnya menentukan berat dari benda yang digunakan untuk kalibrasi dan berat takaran yang di inginkan. kemudian continuous servo akan memutar lead screw sehingga akan mendorong produk empon-empon yang dimasukkan melalui corong menuju load sensor dan ketika takaran emponempon yang ada pada load sensor telah memenuhi dari takaran yang diatur sebelumnya maka, continuous servo akan berhenti berputar. Kemudian emponempon dapat di ambil dan alat bekerja kembali mulai dari awal. Lebih jelas ditunjukan pada Gambar 4. 


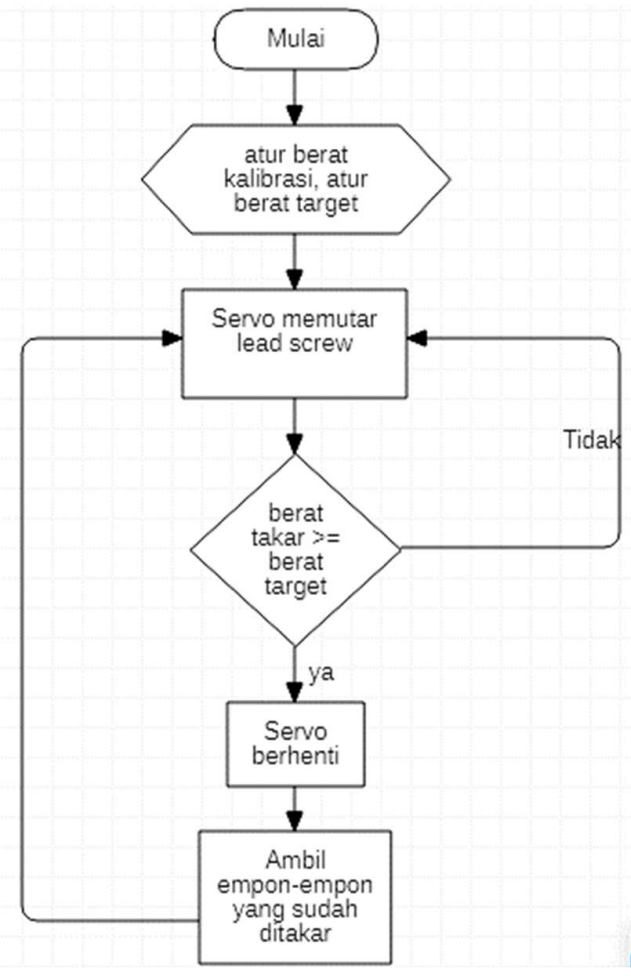

Gambar 4. Diagram alir cara kerja prototype alat takar otomatis

Pembuatan prototype alat takar otomatis dilakukan dengan menyiapakan komponen komponen yang telah disebutkan pada tahapan desain kemudian merakitnya menjadi satu kesatuan. Hasilnya ditampilkan pada Gambar 5.

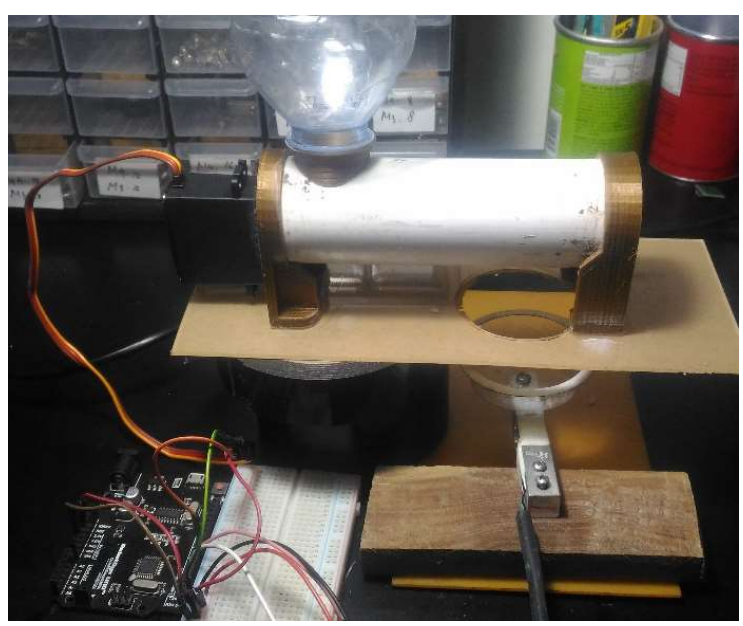

Gambar 5. Hasil perakitan prototype.

Setelah prototype dirakit dilakukan penanaman coding pada Arduino Uno dengan software Arduino IDE seperti
Gambar 7. Sebelum melakukan penanaman coding, mengubah nilai variable y1 (berat benda kalibrasi) dengan berat benda yang sudah kita ketahui nilainya. Dan yt (target takaran) dengan berat takaran yang diinginkan seperti Gambar 6.

float $\mathrm{y} 1=38.0 ; / /$ kalibrasi

float $y t=25 ; / /$ target

\section{Gambar 6. Variabel kalibrasi dan target takaran}

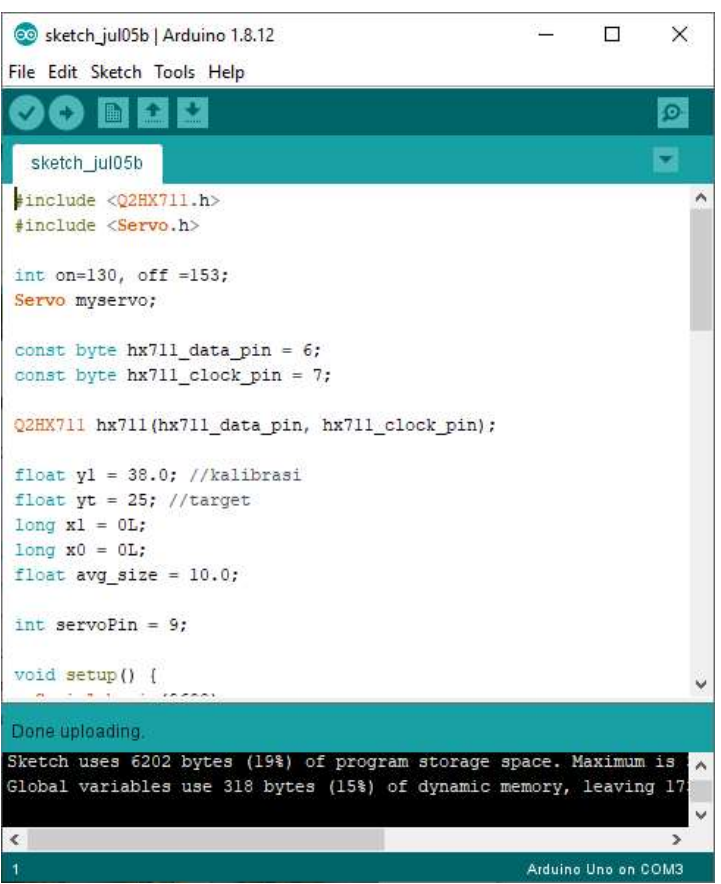

Gambar 7. Proses penanaman coding dengan Arduino IDE

Pada penelitian ini penulis menggunakan baut besi yang ditimbang mengguakan timbangan kue sebagai berat benda kalibrasi (Gambar 8) dan meletakan benda kalibrasi tersebut pada Load Sensor (Gambar 9) Untuk proses kalibrasi, 


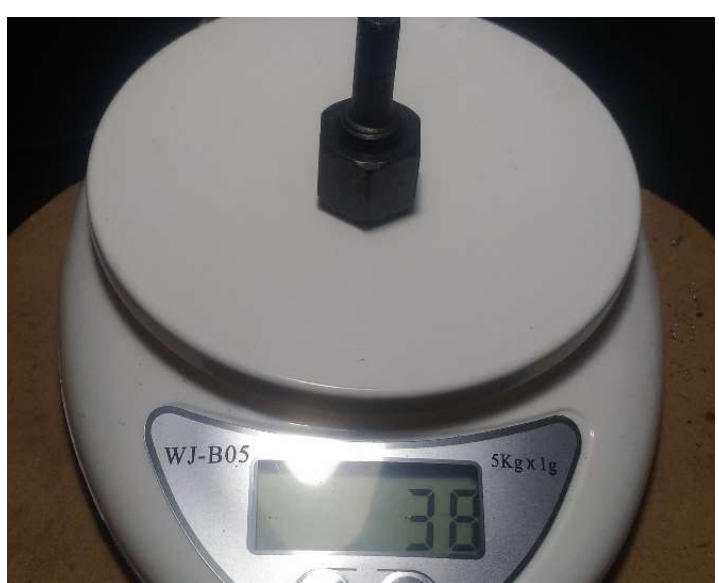

Gambar 8. Benda kalibrasi seberat 38 gram

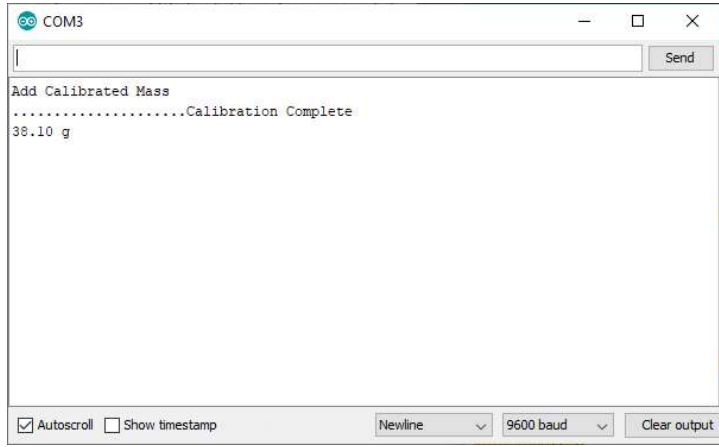

Gambar 9. Kalibrasi berhasil

Adapun kode lengkap program adalah sebagai berikut:

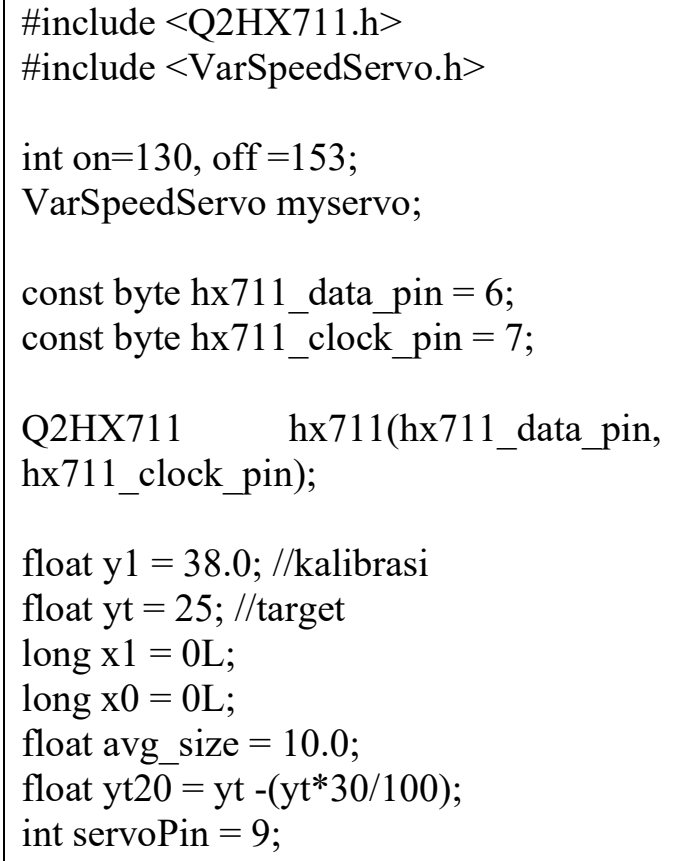

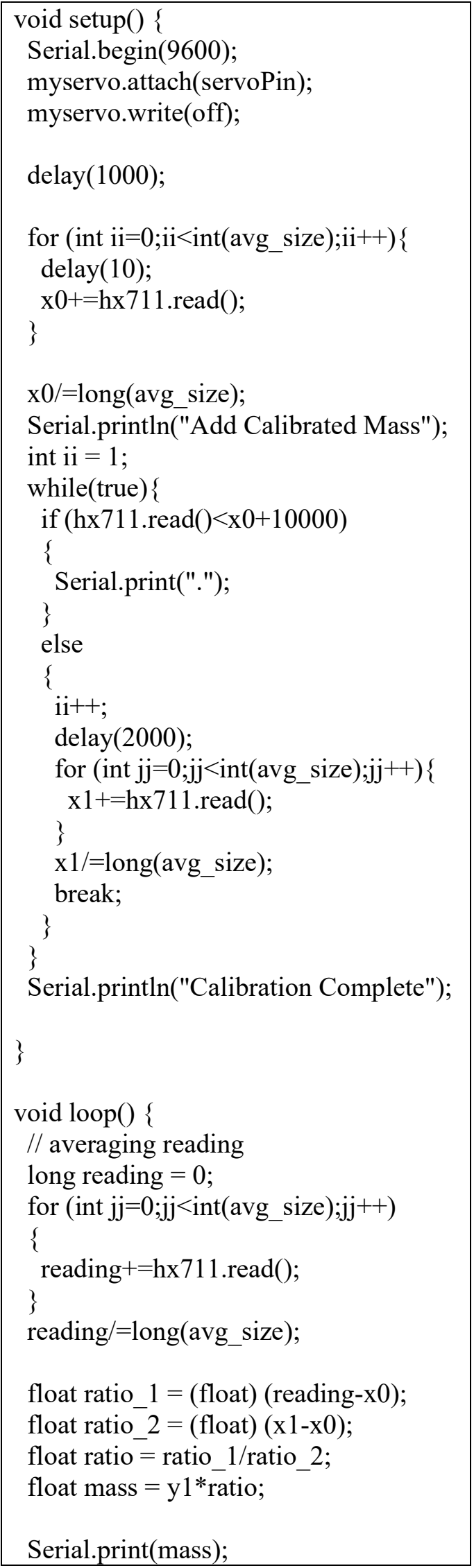




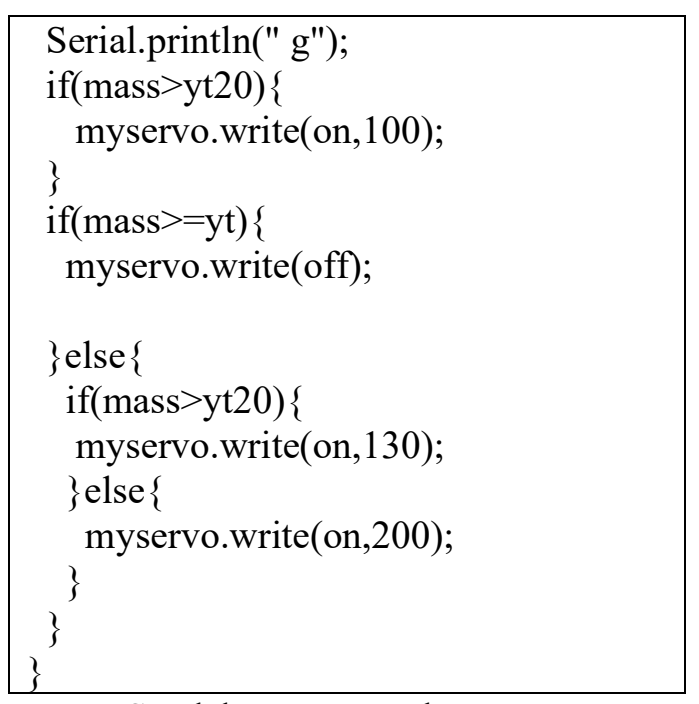

Setelah proses pembuatan prototype selesai dilanjutkan pengujian terhadap kinerja prototype alat takar otomatis yang telah dibuat. Proses pengujian dilakukan dengan memasukan produk empon-empon ke dalam prototype alat takar otomatis melalui corong kemudian hasil takaran akan ditampung pada load sensor.

Pada penelitian ini peneliti menggunakan beras sebagai sampel uji coba dikarenakan prototype yang dibuat terlelu kecil apabila menggunakan emonempon yang rata-rata berbentuk potongan besar-besar.

Pengujian dilakukan 10 kali dengan target 25 gram sehingga diperoleh data sebagai berikut:

Tabel 1. Hasil pengujian

\begin{tabular}{c|cc}
\hline No & $\begin{array}{c}\text { Berat terbaca } \\
\text { pada Sensor }\end{array}$ & $\begin{array}{c}\text { Berat terbaca } \\
\text { pada timbangan } \\
\text { kue }\end{array}$ \\
\hline 1 & 26,55 & 27 \\
2 & 25,88 & 27 \\
3 & 26,34 & 26 \\
4 & 25,21 & 26 \\
5 & 25,97 & 26 \\
6 & 26,31 & 26 \\
7 & 25,32 & 25 \\
8 & 26,48 & 27 \\
9 & 25,96 & 26 \\
10 & 26,51 & 27
\end{tabular}

Dari Tabel 1. Didapatkan selisih berat terbaca pada sensor terbesar dengan target adalah 1,55 gram, selisih terkecilnya adalah 0,21 gram dan rerata selisishnya adalah 1,053 gram. Sementara pada timbangan kue menunjukan hasil bilangan bulat.

\section{KESIMPULAN}

Berdasarkan penelitian diatas dapat disimpulkan sebagai berikut:

1. Penulis telah merancang dan membangun prototype Alat takar otomatis berbasis Arduino uno.

2. Hasil pengujian menunjukkan prototype mampu menakar otomatis sampel dengan rata-rata selisih dengan target sebesar 1,053 gram.

3. Nilai yang ditunjukan oleh load sensor + HX711 lebih detail di banding dengan timbangan kue yang digunakan sebagai pembanding.

\section{SARAN}

Penelitian yang telah dilakukan oleh penulis belum sempurna, oleh karena itu disampaikan saran kepada peneliti selanjutnya:

1. Desain mekanik harus diperbaiki, Jarak load sensor yang terlalu jauh dengan lubang keluar pada barel menyebabkan keterlambatan alat dalam menghentikan servo sehingga mengakibatkan adanya selisih berat yang cukup besar dengan target.

2. Gunakan alat ukur pembanding yang lebih akurat. Disebabkan keterbatasan penulis alat ukur pembanding yang penulis gunakan dalam penelitian ini tidak lebih akurat dari sensor itu sendiri.

3. Tambahkan mekanisme pengambilan hasil takar secara otomatis. Dalam penelitian ini pengambilan hasil takar masih dilakukan secara manual. 


\section{DAFTAR PUSTAKA}

Utami, Mei dkk. 2013. Keragaman dan Pemanfaatan Simplisia Nabati yang Diperdagangkan di Purwokerto. Jurnal

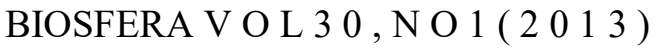

Susanto, Rudi dkk. 2018. Rancang Bangun Alat Ukur Kekeringan Simplisia Berbasis Arduino Uno Untuk Pelaku Usaha Pengeringan "Empon-Empon" di Kismantoro Wonogiri, Jurnal UNISRI

Ge, Ning dkk. 2019. High Precious Weight Meansurement of Liquid Viscosity, 2019 International Conference on Electronic Engineering and Informatics (EEI)

Andrianto, H. \& Darmawan, A. 2017. Arduino Belajar Cepat dan Pemrograman. Bandung: Informatika. 